INTERACTION: Jurnal Pendidikan Bahasa: Vol. 6, No.1: Mei 2019

ISSN: 2406-9558; E-ISSN: 2406-9566

\title{
Students Reading Competence For Detail Information In Expository Text
}

\author{
Nurteteng \\ tetengsyaid72@gmail.com \\ Universitas Pendidikan Muhammadiyah Sorong \\ Dewi Nopitasari \\ dnopitasari_sma5makassar@yahoo.co.id \\ Universitas Negeri Makassar \\ Sumarji \\ sumarji99@gmail.com \\ Universitas Pendidikan Muhammadiyah Sorong
}

\begin{abstract}
The purpose of this reseach to know how the students competence on their reading comprehension especially their ability in getting detailed information in expository text. The population of this research is 10 students of class $\mathrm{X}$ Akutansi SMK Modellink Makbusun. The research used descriptive analysis design. The instrument of this research was the reading test which focused on detail information in expository text. The result of students competence in getting detail information in expository text was $60 \%$ or 6 students got score among 70-100 and it was catagorized into good score. The other students or 2 students got in catagorized at "poor" catagory. The average of score students was 71.6. The competence of students in getting information in expository text was catagorized into "good" category.
\end{abstract}

Key words: Reading Competence, Detail Information, Expository Text

\section{INTRODUCTION}

In the era Globalization or modern and information English has an important role. English as an International language is widely spoken by people all over the world. That why the people should learn English in formal and informal education. Reading is the single most important subject taught in school without it students are barred from learning every other academic school subject, language, social studies (Putra, 2005). A student's success in any one of these subject depend on the extent of this reading, and ability to read and read well (Pirrozi, 2002). Reading is more and more for the complex socety every day in the reading activities, sign of road were directed the people to headed, information for driver about dangerous sign in the road and remind the police law (Rozziwela, 2010). The people in look work vacancy by magazine and read in the vacancy column. 
Reading is one of language skill that is very important to get more information and pleasure from what we have read. For example about science, technology and art, to increase our insight or knowledge For that reason reading skill must be learned by the students, of course the reading material which is given in learning process must suitable with their individual developmental level in order they are motivated in reading. On the other hand, for students reading is something crucial and indispensable to be success depends on their ability to read. Reading skill is demanded in reality life every day. Although the information can be gotten from another media like Television and Radio but reading activeties cannot be avoided. Reading activities remain important in society. Reading ability is vital necessity in education, the students must have good reading intensive than society in general, and students' duty is learning, and learn ( (Brown, 2007)).

According to the writer's observation, the students' reading skill of SMK Modelling X Akutansi still low. They still had difficulties in understanding the text. The texts which were taught in the first grade of Senior High School were descriptive, news item, and narrative. Based on the observation in the classroom and the interview with the teacher and the students, the writer found that they had difficulties in expository text for detail information. They got difficulties in understanding the characteristics of the text including the social function, generic structure, and language feature. The generic structure includes finding detail information and determining the parts of the text. While, the language feature includes vocabulary, finding references, and understanding the tenses.

\section{LITERATURE REVIEW}

\section{Previous Study}

Nurdiyanti (2010) researched about improving students' reading comprehension through reading aloud at the Second Year of SMP Muhammadiyah Aimas. From the data result we know that the students' interest in reading is very high. The test is the only instrument to measure the students' ability in comprehends the reading text. The test itself is done two period are first is pretest than the second is post test in form of multiple choice and essay. quantitative descriptive also choose as a method in analyzing the data before finally calculate using statistical formula that is t-test, in the discussion, the writer present the data presentation, data analysis and interpretation of the result of applying instrument. From her finding, the writer concluded that the reading aloud technique is effective to use in teaching reading comprehension.

Nurteteng (2018) investigated about the students personality based on the reading strategy used. There are three points were found from this reserach. First, regarding with the students personality, mostly students in SMAN 6 Wajo are extrovert persons. The rest of students is dominated with introvert personality. Second, the reading 
INTERACTION: Jurnal Pendidikan Bahasa: Vol. 6, No.1: Mei 2019

ISSN: 2406-9558; E-ISSN: 2406-9566

strategy that the student most frequently used is Global Reading Strategy. It is followed with Problem Solving Strategy and Support Reading Strategy. Last, related with the relationship between reading strategy used and the students personality, there are three points we got from this study. Fisrt, Global Reading Strategy is commonly used by extrovert students. Second, Problem Solving Strategy is used by introvert students. Third, Support Reading Strategy is used by thinking students.

\section{Some Pertinent Ideas}

\section{Reading}

Reading is a medium of knowing or understanding text that needs particular attention and concentration. It is one of specific abilities which helps people understands and catch the message of the text. William (1984) stated that reading is a process whereby one looks at and understands what has been read. Moreover, reading is eye working processes that information transfers into brain for produce the information. Harmer (1985) states that reading as an exercise dominated by the eyes and the brain". Furthermore, reading is essential skill that supports students in teaching and learning process, national examination, even in proficiencies test (TOEFL and IELTS). Pintrich et.al. (1999) state that reading is a crucial skill for professional successful and academic learning. In some academic subject areas, school success is dependent on knowing how to read, understand what has been read, and apply the content to future learning.

Zare, et.al (2013) comment that reading is a cognitive activity in which the reader takes part in a conversation with the author through the text. In addition, Rivers (1987:674) states that reading comprehension entails more than knowledge of vocabulary and syntax. It also requires ability to perceive the exact nature of being communicated.

\section{Expository Text}

Most expository texts are structured to facilitate the study process for prospective readers. These texts contain structural elements that help guide students through their reading. Authors of expository texts use these structures to arrange and connect ideas. Students who understand the idea of text structure and how to analyze it are likely to learn more than students who lack this understanding (RAND Reading Study Group, 2002). The research literature in this field reveals that students' reading comprehension skills improve when they acquire knowledge of texts' structural development and use them properly.

Carrel (1985) argued that instruction on text structure indeed has a positive effect on the students' recall protocols. Meyer (1985) stated that knowledge of the rhetorical relationship of the ideas-main idea, major ideas, and supporting details-helps readers with their comprehension of the expository texts. Reading researchers have argued that knowledge of text organization or structure is an important factor for text comprehension. Structural elements in expository texts vary; therefore, it is important 
to introduce students to the components of various texts throughout the school year. It is also important to teach and model the use of these components properly at the beginning of the school year. The recognition and use of text organization are essential processes underlying comprehension and retention. As early as the third grade, students are expected to recognize expository text structures (Meyer, 1985).

\section{METHOD}

\section{Design and Sample}

In this research, the writer using descriptive analysis method. The writer wanted to know the competence or ability of reading competence for detail information in expository text method to students reading comprehension. To investigate it, he will give score the students' after they had reading expository text, the writer test students reading skills by using test, especially in expository text. The population of this research is the students in the first grade of SMK Modelling Makbusun. In this study the writer took sample 10 students and all of them are female.

\section{Instrument and Procedure}

The instrument that was used to collect data for this study was an essay test. The test consists of 10 items number with two different texts. The text that used is expository text and each text have five question that should be answer by the students. The test is using to know the students reading competence for detail information in expository text.

\section{Data Analysis}

The data which was gotten in the research has been analyzed using the following the formula was used:

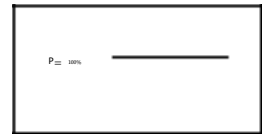

Mean:

$\mathrm{P}=$ the percentage of score.

$\mathrm{F}=$ the frequency of the incorrect answer.

$\mathrm{N}=$ the number of respondent

In calculating the percentage the writer used the following formula.

$\mathrm{P}=$ the percentage of the score
$\mathrm{F}=$ the frequency of the incorreet answer.


$\mathrm{N}=$ the number of respondent

$\mathrm{n}=$ number of item test

\section{RESULT AND DISCUSSION}

The writer gave the test to the first grade students' of SMK Modellink Makbusun which the test 10 item essay consist of 2 expository text, in this research the writer had used question in expository text reading comprehension. After got the data and than the writer done tabulation of data. The table below is the result of the students score.

Table 1

The score of students based on instrument I and instrument II

\begin{tabular}{|c|c|c|c|}
\hline \multirow[t]{2}{*}{ No. } & \multirow[t]{2}{*}{ Students } & \multicolumn{2}{|l|}{ Score } \\
\hline & & Instrument I & Instrument II \\
\hline 1 & S1 & 85 & 75 \\
\hline 2 & $\mathrm{~S} 2$ & 85 & 100 \\
\hline 3 & S3 & 27 & 75 \\
\hline 4 & S4 & 70 & 75 \\
\hline 5 & S5 & 85 & 80 \\
\hline 6 & S6 & 45 & 60 \\
\hline 7 & S7 & 85 & 80 \\
\hline 8 & S8 & 50 & 90 \\
\hline 9 & S9 & 55 & 80 \\
\hline 10 & $\mathrm{~S} 10$ & 40 & 90 \\
\hline & average & 62,7 & 80,5 \\
\hline
\end{tabular}

Based on the test in expository text the writer was seen the score of answer test. That consist of 10 question, maximum score is 100 point. The highest score in instrument I was 85 point and the lowest was 27 points.with the average score in instrument I was 62,7 . In instrument II, the highest score was 100 point and lowest was 60 point. The average score of instrument II was 80,5 point.

Table 2

The score of the students based on both instrument.

\begin{tabular}{|c|l|c|}
\hline No. & Students & Score \\
\hline 1 & S1 & 80 \\
\hline 2 & S2 & 92,5 \\
\hline 3 & S 3 & 51 \\
\hline 4 & S4 & 72,5 \\
\hline 5 & S5 & 82,5 \\
\hline
\end{tabular}


INTERACTION: Jurnal Pendidikan Bahasa: Vol. 6, No.1: Mei 2019

ISSN: 2406-9558; E-ISSN: 2406-9566

\begin{tabular}{|c|l|c|}
\hline 6 & S6 & 52,5 \\
\hline 7 & S7 & 82,5 \\
\hline 8 & S8 & 70 \\
\hline 9 & S9 & 67,5 \\
\hline 10 & S10 & 65 \\
\hline & Average & 71,6 \\
\hline
\end{tabular}

On the table 2 showed the score based on the test essay in instrument I and II. The highest score was 92,5 point and the lowest was 51point.The mean score of both instrument was 71,6 point.

Table 3

Classification of students' competence

\begin{tabular}{|c|l|c|c|}
\hline No. & Students & Score & Classification of the competence \\
\hline 1 & S1 & 80 & very good \\
\hline 2 & S2 & 92,5 & Excellent \\
\hline 3 & S3 & 51 & Poor \\
\hline 4 & S4 & 72,5 & Good \\
\hline 5 & S5 & 82,5 & very good \\
\hline 6 & S6 & 52,5 & Poor \\
\hline 7 & S7 & 82,5 & very good \\
\hline 8 & S 8 & 70 & Good \\
\hline 9 & S9 & 67,5 & Fairly \\
\hline 10 & S10 & 65 & Fairly \\
\hline & Average & $\mathbf{7 1 , 6}$ & Good \\
\hline
\end{tabular}

Based on the table 3, can be seen classification of students competence everyone got both score and classification of the competence, the higest score was 92,5, it was catagorized in excellent. The lowest score was 51,it was catagorized in poor. The score for all students divided into score 90-100 was a students and catagorized into excellent. The score 80-89 was 3 students and catagorized into very good. The score 70-79 was 2 students and it was catagorized into good.the score 60-69 was 2 students and it was catagorized into fairly. The score 50-59 was 2 students and it was catagorized into poor.

Based on the finding or the data in table 1, it was presented the score of it students in instrument I and instrument II. In instrument I, the students got score above 70 or more was 5 students or $50 \%$ of students, and the other got score under 70 . So the avarage score of the students in instrument I was 62,7. At the instrument II the students got score 70 or more was 9 students or $90 \%$ of students, and the other or just one students got score under 70.the avarage at instrument II was 80,5. 
INTERACTION: Jurnal Pendidikan Bahasa: Vol. 6, No.1: Mei 2019

ISSN: 2406-9558; E-ISSN: 2406-9566

The students mastery at first grade students of SMK Modellink Makbusun in reading competence for detail information in expository text was catagorized into" good"catagory. Because based on the finding of research $60 \%$ of students got score 70 or more, and that score was categorized into "good" until "excellent" catagory. The other students got score under 69 as much $40 \%$ or divide $20 \%$ for categorized in "fairly" catagory, and $20 \%$ of student also categorized into "poor" catagory. Based on explaination, the competence of students in getting detailed information in expository text can be catagorized in good catagory. The students can got the information from the text in instrument or test given by the writer. They can gave the information based on the text that match with the question. Eventhough there were students still gave information incompletly.

\section{CONCLUSION AND SUGGESTION}

Based on the result of study, the writer concluded that the students mastery at first grade students of SMK Modellink Makbusun in ordering reading competence for detail information was catagorized into "good" catagory. The average students score in getting detail information in expository text was 71.6. The percentage of students who got score 70 or more was $60 \%$, and under 70 was $40 \%$. Some suggestion from the writer to the students and the English teacher in ordering adjective to avoid the students reading competence for detail information. The students should be more intens for reading a book, newspaper, magizene, letter, article, etc and sharing information with the other friends and the students had doing activities to practice reading in front other they friend. The teacher should use or try with reading competence for detail information and focus in expository text, the students had much reading to get the information in expository text, and the teacher should be oftenly invite the students to read in library for reading togethe

\section{REFERENCES}

Brown, H. D. (2007). Principles of Language Learning and Teaching. New York: Pearson Education, Inc.

Carrel. (1985). Text Genre. New York: Longman.

Harmer, J. 1985. The Practice of English Language Teaching. United States of America: Longman

Pintrich, R.E., Romeo,G.C., \& Muller, S.A.B. 1999. Integrating Reading Strategies into the Accounting Curriculum. College Student Journal. 33(1): 77-82

Meyer, G. (1985). Reading Comprehension in Depth. New York: Longman.

Nurdiyanti, U. (2010). Improving Students Reading Comprehension through Reading Aloud at the Second Year of SMP MUhammadiyah Aimas. Sorong: STKIP Muhammadiyah Sorong.

Nurteteng. (2018). The Students Personality Based on The Reading Strategy Used. Exposure: Jurnal Pendidikan Bahasa Inggris, 192-204. 
INTERACTION: Jurnal Pendidikan Bahasa: Vol. 6, No.1: Mei 2019

ISSN: 2406-9558; E-ISSN: 2406-9566

Pirrozi, A. (2002). Critical Reading, Critical Thinking Focusing on Contemporary Issues. New York: Pearson Education, Inc.

Putra, H. A. (2005). Students Reading Comprehension in reading English Article. Padang: Universitas Negeri Padang.

Rivers, W. M. 1987. Teaching Reading Comprehension: An Interactive Pedagogie.

New Jersey: San Fransisco State University

Rozziwela, R. (2010). The Students' Genre Awareness And Their Reading Comprehension Of Different Text Types. International Journal Of Asian Social Science, 460-469.

William, E. 1984. Reading in the Language Classroom. London. McMilan.

Zare, P., \& Othman, M. 2013. The Relationship beween Reading Comprehension and Reading Strategy Use among Malaysian ESL Learners. International Journal of Humanities and Social Science, 3 (13).Accessed on October, $9^{\text {th }} 2015$ 